\title{
THE BATTLE OF WARSAW AND ITS PROJECTIONS IN POLISH-UKRAINIAN RELATIONS (1920-2020) ${ }^{2}$
}

Key words: The Battle of Warsaw, ideology of 1920, social and national elites, silence / distortion of the past, the perspective of long duration.

\begin{abstract}
The Great War brought about the collapse of the old world order of the 19th century. The idea of the self-determination of nations, e.g. Ukrainians, Finns, Latvians, Lithuanians, Poles, etc., or multi-ethnic societies, e.g. Czechs and Slovaks, Slovenes-Serbs-Croats-Bosnians, etc., guided the new political order in Europe in 1918-1919. It was only partially possible to implement it due to the powerful influence of nationalism or (neo)imperialisms, such as in Soviet Russia and the USSR, or later with the Third Reich. In 1920, the societies of Ukraine and Poland tried to find an indirect path. The Polish-Russian / Soviet-Ukrainian war, symbolized by the Battle of Warsaw in 1920, turned out to be a breakthrough in these actions. On the basis of the effects of this so-called "dwarf war"3 gave rise to a new political and ideological imperialism in the USSR, as well as an ideology (1920) as a platform for cooperation and understanding between Poles and Ukrainians.
\end{abstract}

1 Professor at the Pomeranian University in Słupsk, Poland, roman.tomaszewski@ apsl.edu.pl.

2 The text is an attempt at a synthetic approach to a set of issues, each of which could be the subject of a separate dissertation. However, taking into account the already relatively large historiographic achievements devoted to the individual historical facts, a detailed development of some of the issues discussed below, as well as their documentation, would adversely affect the transparency of deliberations. For this reason, the studies cited further in the footnotes are treated selectively. Text translation Małgorzata Irena Kowalczyk.

3 Translator's note: $d w a r f-$ here means a state that is not a superpower. 
Contrary to all assessments or interpretations, the signalled ideology of 1920 is a constructive factor in the history of Poland and Ukraine, based on the effects and experiences of the war of 1920-1921. This text is an attempt at a synthetic look at the genesis of the Polish-Russian / SovietUkrainian war, mainly at its long-distance effects felt later in the Third Polish Republic and in free Ukraine in 2020. Perhaps these impact were also felt on a wider European scale. The text does not so much judge or evaluate the results of the previous research, but is an attempt to organize and generalize them. It may be a proposal for a possibly balanced view in the elites of both societies, a past that determines the future of Poland and Ukraine. Finally, it is an attempt to establish a long-term perspective that reduces political or (neo)nationalist emotions in favor of a balanced orderliness of knowledge.

The essence of phenomena, processes or crucial historical events, and the Battle of Warsaw of 1920 is undoubtedly one of them, is best captured by getting to know the genesis and long-distance effects. The course of events itself creates the necessary background, but it is closer to the timeline of events. The series of military, political and social events of August 1920, symbolized by the Battle of Warsaw, is a breakthrough in PolishRussian/Soviet-Ukrainian relations, although it is symbolized by the term "battle". The settlement of these battles led to the real end of the Great War, with its final phase known as the "dwarf war". The parties to the decisions made at that time did not have full subjectivity before - at least until the end of 1916. They obtained it and expanded upon it in the course of the events of 1917-1919.

By 1917-1918, Polish statehood was restored, and the "Polish cause" appeared in the international sphere, going beyond the internal issues in Russia. The critical path was to recreate the state in two phases. The first, between November 1916 and July 1917, included:

- establishment of the Polish administration;

- transformation of the Polish Legions into a regular army;

- Polonization and expansion of secondary and higher education.

However, in the second phase, between August 1917 and February 1919, the following critical phenomena or events turned out to be:

- the oath crisis of the Polish troops; 
- gradual liberation from the protection of the Central Powers, or even breaking with them as a result of the Brest Peace (February 9, 1918 and March 3, 1918);

- creation of classified structures (political or military) - the growing importance of the Polish National Committee (KNP) in the Entente countries, until Poland was formally recognized as an allied party (June 3, 1918).

Both phases, despite not always favorable events, meant a gradual and constant increase in Polish potential in all partitions and in the Entente countries - in particular in France, Canada and the USA (Tomaszewski, 2015, pp. 27-98; Tomaszewski, 2019, p. 19-72). It should be noted that the factual findings concerning the Polish issue (from its origins to the midtwentieth century) are relatively well documented. The reference to this voluminous fact (devoted mainly to the single or fragmented events) should now be reduced in favor of a search for a more balanced syntheses.

In the same period, the Russian Empire experienced a crisis. First, as a result of both revolutions; then because of the chaos in both imperial (Russian or Soviet) and local structures. Under these conditions, there was an attempt to create a Ukrainian state in stages from vacuum (it meant a transition from autonomy to building statehood). As in the case of Poland, it happened in two phases. The first phase was based on the idea of autonomy and included:

- the fall of the monarchy and the reduction of the importance of the central government;

- the second Russian offensive (under Gen. Briusilov) and the breakdown of army discipline resulting in chaos and anarchy - an attempt to build the autonomy in the Ukrainian area of the Empire (in the region not occupied by the central states);

- establishment of the Ukrainian People's Republic with its own administration and army;

- the conclusion of the Brest Peace and allied relations with Central Powers.

The second phase consisted of successive attempts to implement a program of maximum territorial development in the Ukrainian state on the basis of open or secret arrangements related to the Brest Peace, and at the 
same time a relatively lengthy security presence by the Central Powers. During this period, it should be emphasized:

- 3-4 transformations of the state's political system, up to and including the merger of two Ukrainian republics';

- lack of international recognition (the Ukrainian issue was treated as an internal Russian matter) and the loss of the Central Powers' protection as a result of their defeat;

- the necessity to wage war on several fronts and the resulting increased threats - divergent attitudes of Ukrainian politicians;

- several attempts to mobilize without minimal preparation in the civil and military branches of the administration, without organizational and material preparation ${ }^{5}$;

- constant increase in anti-Polonism 6 .

Both young Ukrainian states as well as the Polish state pursued a wishful policy until mid-1919, and their development was asymmetrical. The Ukrainian potential was gradually exhausted, and the potential of a reestablished Poland was constantly growing. It should also be noted that despite the fighting in Eastern Galicia, the Polish side was still aware of the need to support an independent Ukraine. An obvious dilemma was the establishment of a line of separation between the states in the event that a federal concept could not be implemented, while maintaining the balance between ethnic minorities on the Polish and Ukrainian side. This was the essence of Józef Piłsudski's initial proposals and most of the variants put forward by the representatives of the Entente. Various options emerged in Ukrainian political circles: pro-Bolshevik, pro-Russian (Ukrainian National Committee - S. Markotun) ${ }^{7}$ (Pisuliński, 2013, p. 293), German (General Wilhelm Grőner, Wilhelm Habsburg, Hetman Skoropadski) (Bruski, 2000. p. 328-337; Snyder, 2010), Czechoslovakia (contin-

${ }^{4}$ The situation was complicated by the creation and periodic operation of 5 Ukrainian state organizations or quasi-state organizations.

${ }^{5}$ The patriotic involvement of the pro-Ukrainian independence elite would not be a sufficient substitute, dictated by the realities of the time.

${ }^{6} \mathrm{I}$ am invoking this as a fact and not as an objection.

7 Even when the UPR tried to return to the variant of autonomy within Russia, it was marginalized by the command of the troops of Southern Russia in favor of S. Morkotun. 
gent protectorate on behalf of the League of Nations). The actions of subsequent Ukrainian authorities in Kiev between February and December 1918 resulted in the strategy of consistent implementation of the Brest Peace arrangements, and the merger of the two countries of the Ukrainian People's Republic (UPR) and the West Ukrainian People's Republic (WUPR) in January 1919 confirmed the continuation of the maximum program. The elimination of the Central Powers from decision making on the Ukrainian question made this position risky. In particular, this jeopardized the UPR's efforts to gain international recognition by the Entente. The Polish side consistently maintained in Kiev the diplomatic mission of the Regency Council, with the participation of the Polish Armed Forces (PSZ - Polnische Wehrmacht), i.e. Major Juliusz Kleeberg, and due to the stationing of Polish military corps separated from the Russian army until the end of May 1918. They were one of the few units separated from the former Russian troops that did not become demoralized. Although they were disarmed by the Germans at the end of May 1918, most of the soldiers of these formations were sent to the Polish Armed Forces under reconstruction in autumn. The migrations of experienced Polish veterans from these formations took place against the command of Ober-Ost, which did not agree to merge these three corps with the Polnische Wehrmacht (Royal Polish Army) and subordinate them to the Regency Council in Warsaw (Dąbrowski, 2015, pp. 284-285; Holzer, 2008, p. 28).

The diplomatic representation in Kiev was then taken over by the Republic of Poland and was consistently maintained until the evacuation (February 1919) to Odessa. We can speak of an asymmetric attitude of the UPR government, which used the method of incidental contacts with Warsaw by unofficial envoys, and these contacts also ceased as a result of the merger with the WUPR. From that moment on, one can speak of the "reactive diplomacy" between Poland and Ukraine until the end of 1919. The extent of these incorrect assumptions in the foreign policy of both Ukrainian states of disregarding Poland as a member of the Entente from June 31918 in reference to the intermediation of other states - parties to the victorious Entente, the negotiations in Paris in May 1919 showed. As a result, there was a definite refusal of international recognition of the UPR, which took place on June 30,1919. The victorious states consistently 
maintained in 1919 that the Ukrainian issue was an internal Russian problem, and thus eliminated the effects of the Brest Peace. This meant that Brest weighed negatively on Ukrainian relations with the Entente, and yet it continued to function as a myth and a basis for a rigorously maximized program undertaken by successive Ukrainian national movements. This is confirmed by the claims made in August 1919 by the Ukrainian side in the armistice talks with Poles in Lviv and Dęblin. Only then was the Ukrainian Extraordinary Diplomatic Mission of Filip Pyłypczuk sent to Warsaw (Klimecki, 2002, pp. 14-23). At that time, however, there were completely different conditions that restricted the official actions of Warsaw, which was forced to respect the Paris provisions. Thus, one can speak of Ukraine's international self-isolation, which rules out any doubts or gives rise to a sense of marginalization - perhaps the accusation that Ukraine as the weaker party was disregarded in the negotiations of 1918-1919. However, the as yet uneducated and, above all, inexperienced Ukrainian political class was unable to balance the balance between the utopia of the maximal program, along with the incriminating participation of the Central Powers as the losing party, and the attitudes and realities driving the victorious Entente camp. The struggle of the united Ukrainian states (the UPR and the WUPR) with everyone and against everyone in 1919 did not give the Ukrainian elite a good legacy - it only proved a policy of unrealistic demands and a persistent disregard for reality. As a result, unattainable goals were set for Ukrainian society and people in state of war fatigue.

The appearance in Warsaw in the autumn of 1919 of the Ukrainian Diplomatic Mission of Andrei Lewytsky in Warsaw, representating the UPR-WUPR, made it possible only in November to develop a draft declaration as the basis for an agreement between the parties (November 30, 1919) and to present it to Polish partners. As early as December 2, 1919 it was lost by the Galician members of the mission. An audience granted by Józef Piłsudski on December 15, 1919 to Stepan Wytwycky, the leader of the Galician members of the Ukrainian diplomatic mission, should be considered a symbol of the pragmatic approach. The Chief of the Polish State pointed out that the Ukrainian side, including its Galician component, could not deal with the Ukrainian issue in a social and political void 
with a wishful thinking. In Piłsudski's opinion, the attitude that ignored the existence of Polish society, together with its aspirations and consistent implementation, proved the utopian nature of such a policy. Already the negotiations of the Ukrainian elite of Eastern Galicia during the negotiations with Czernin initiated this attitude at the end of 1917, which was persistently implemented until March 15, 1923, although at that time Count Czernin and the state he represented had gone into oblivion. It was in the myth of Brest and in the attitudes of Ukrainian politicians from Eastern Galicia that the genesis of the political line of the 'all or nothing (Dąbrowski, pp. 273-280; tomaszewski, 2019, pp. 41-46). At that time, the Polish leader emphasized the negative position of the Western powers towards the prospect of establishing a Ukrainian state, and at the same time the lack of an alternative other than a full Polish recognition for the Ukrainian side. On the other hand, the very fact of receiving the Ukrainian adversary by the Chief of State was symbolic. Stepan Wytwycki represented a consistently tough, uncompromising approach. He denied the possibility of the Polish-Ukrainian border on the Zbruch River ${ }^{8}$ (Łysewicz, 1997, p. 98). The practice of the following months, despite the fact that the alliance was established in April, however, proved the lack of coordination of Ukrainian political and military efforts.

The year 1920 and the entire Polish-Soviet-Ukrainian war are symbolized by the "Battle of Warsaw" fought in the northern and eastern outskirts

8 The assessment by prof. Ivan Lysewicz of the Institute of History of the Kiev Academy of Sciences is against this. He claims that despite the consent of the Ukrainian delegation to establish the border on Zbruch, expressed in the declaration of December 2,1919 , the Polish side broke off the negotiations. He also claims that in the autumn of 1920 and the winter of 1921, Poland was terrified of a war with Soviet Russia and abandoned its Ukrainian ally In this context, how should the Ukrainian declaration of Stepan Wytwycky of 6 December 1919 be assessed? - the validity of the opinion of prof. Lysewicz in this context is at least doubtful. It may be possible to practice wishful politics or propaganda, but there is no concept of wishful science. In terms of realism, the decisions of Polish politicians made between October 1920 and March 1921 should be assessed on the basis of the exhaustion of the potential of the state and Polish society. Similar realism and similar assessments characterized the group of politicians gathered around Symon Petliura in this breakthrough period, despite the accompanying feelings of bitterness. 
of Warsaw between August $10^{\text {th }}-20^{\text {th }}, 1920$. It is a commonly accepted definition (though imprecise) of the cycle of armed clashes in a suburb of Warsaw along with the Polish offensive turn from the north, the so-called "Battle of the Wkra" - relieving the effort around defensive stands; lastly the operation of the Polish army from the Wieprz River to the rear of Soviet Russia, which was tied up in the outskirts of Warsaw. These 10 days of intense combat operations around Warsaw marked a breakthrough in the war prepared from the end of 1919 and ended in 1921. It cannot be treated as a part separated from the whole political, military or ideological effort of the parties of the conflict. After all, both the Poles and Ukrainians prepared their own strategies and consistently implemented them despite fluctuations, twists, and during the crisis at the turn of July and August 1920. It is therefore worth noting the stages of this war.

The phase of building a Polish-Ukrainian alliance was parallel to the consolidation of The Red Army (Workers' and Peasants' Red Army, WPRA) which lasted from February 1918, and the course of the civil war in the former empire. The Polish Army entered into combat with the Soviet troops relatively late, when its structures had already been stabilized by integrating the PAF (Polish Army Forces, Polnische Wehrmacht) with the Greater Poland Army and the General Józef Haller's (so-called) "Blue Army". At the same time, the Polish-Ukrainian military dispute in Eastern Galicia and Volhynia was resolved. In the summer of 1919, the structures of the Polish state were already fully formed, and the Polish Armed Forces organization moved from a voluntary phase to regular conscription based on a legal obligation of military service. The political background was the cooperation of all major Polish political forces, symbolized by the coordination of the actions of Roman Dmowski and the Polish National Committee in Paris and in the Entente structures with the actions of Józef Piłsudski and the authorities in the country. Only Polish communists excluded themselves from this process. As a result, in 1919, it was possible to create an effective administration and, to a large extent, unite the Polish military with the former partitioning armies, the auxiliary Polish formations in Russia and Austria-Hungary, the troops subordinate to the Regency Council of the Kingdom of Poland, and the Polish National Committee in Paris. In 1920 , approximately 32,000 officers from the former partitioning armies 
along with approximately 3,000 graduates of Polish officer schools served in the Polish Army. This number included many professional officers and a relatively large group of certified officers (of the general staff). Almost everyone had war experience. In 1914, a total of 11,000 people served in the partitioning armies. professional officers of Polish origin, and this number was completed by approx. 31 thousand. reserve officers. This means that the share of the Polish intelligentsia in the officer corps of the partitioning powers was significant. These officers did not boycott the services in the armies of the countries of their citizenship, and their number was a function of the number of Polish educated classes. The cautious attitude of the Polish military authorities to the mobilization of some of the ensigns of the former Russian army in the buildup of the war years 1916-1917 should be emphasized (due to the ensigns limited competences) (Tomaszewski ed., 1997, p. 76-77, 184-185). There was also a relatively large political and administrative base owing to officials of Polish origin from Galicia, and the participation of Polish factions in the Russian Duma, the Austrian Imperial Council and the German Reichstag. Between 1918 and 1920, there was also a wave of Polish educated classes returning from emigration. As early as 1917, a specific forum for the exchange of views among the Polish elite functioned in the form of an inter-partitioning ${ }^{9}$ organization called the League of Polish Statehood.

The years 1915-1918 were a period of consolidation for the Polish political class and local governments administration in the territory of the German and Austro-Hungarian occupation. In addition, in the next stage, from July 1919 to April 1920, stabilization took place, enabling the improvement of state structures, administration, training and harmonization of the Polish Armed Forces mainly on the foundation of the German military experience ${ }^{10}$. Therefore, the opinion of January-February 1919

9 Translator's note: inter-partitioning - means an organization operating in all parts of Poland included into Germany, Russia and Austria.

10 Apart from the Blue Army, most of the Polish military formations were organized on the German model. In practice, the divisions originating from the Polnishe Wehrmacht (Royal Polish Army)or from Greater Poland were, in a sense, a variant of the model of the German troops. It also influenced their behavior in the anarchized area of Ukraine in 1920. 
given to the authorities of the UPR in Kiev by Viacheslav Prokopovych and Joachim Wołoszynowski regarding the social destruction of Poland was wrong. On the other hand, the expertise of General Mykola Kapustiansky from the same period about the weakness of Ukrainian troops and international isolation (as particularly negative determinants of the prospects of the UPR) was accurate - although in this vision of an educated officer it was an axiom to refer to the findings of the Brest Peace. The presupposition being the Brest Peace would be accepted by the Entente for returning the UPR to the structures of Russia (Klimecki, 2002, pp. 15-16). Therefore, the expertise was also wishful.

The following months of 1919 indicated the exhaustion of the UPR's potential and the growing discrepancies in the circles of the Ukrainian elite. It is difficult to determine the effectiveness of the nascent Ukrainian administration and the Ukrainian army between 1917 and 1920, because in practice it meant the necessity to Ukrainianise the Russian structures that had already been destroyed. The long process of culturally absorbing the educated layer of Ukrainian origin by Russia, its culture and education system, significantly limited the possibilities of the UPR. The same was true of the military cadres that could be taken over from the anarchic Russian army. That is why the hetman period was characterized as one of highest efficiency state-building, despite its shortcomings. Firstly, because it became possible to refer to the Russian cadres more fully. The merger of the UPR with the WUPR only partially improved the social situation in both countries. In Eastern Galicia, the very act of establishing state structures in the autumn of 1918 was anticipated by preparations of 1917, made possible by, inter alia, the deputy of the imperial governor of Galicia, Wołodymyr Decykewycz. Militarily there were objective limitations resulting from the number of the Ukrainian Sich Riflemen Legion (approx. 2.500 legionnaires) and the number of Ukrainian classes educated in Eastern Galicia, which reduced the number of professional officers (approx. 100) of Ukrainian origin in the Austro-Hungarian army and reserve officers. These restrictions in particular applied to senior officers or the general staff, which in the future led to the use of cadres from the former Russian army, or officers of German or Czech nationality from the former Austro-Hungarian army. Generally speaking the UPR and the 
WUPR, as they relate to the first forms of Polish statehood from 19161918 , the relative balance in the demographic and social potential of Poles and Ukrainians should be taken into account and emphasized. Differences resulted mainly from a qualitative factor (literacy, the number of elites, the number of military personnel, the level of national awareness) and a disproportion in emigration resources. The Ukrainian elite was dynamic, but small in number and largely lacking any political experience. The formation of a modern nation in Ukrainian society was delayed and took more time (Handelsman, 1993, p. 31-35). The Ukrainian emigration was twice as low as the Polish and in 1920 still poorly organized. Contrary to the situation after World War II and the strengthening of Ukrainian ethnic groups in the USA, Canada, Germany, Great Britain and France, and partly also in South American countries by Ukrainians involved in military, political, economic collaboration or a relatively large number of Ukrainians who found in the western zones of occupation of Germany. An example is the Ukrainian diaspora in Winnipeg in Canada or the post-war Ukrainian emigration in the USA (Szlachtycz, 2008, p. 290; RossolińskiLiebe, p. 823). The excellent organization of the Ukrainian circles in Canada, the USA and the Federal Republic of Germany after 1945 should be mainly due to the domination of emigrants coming from the Ukrainian military formations from the Second World War, with a nationalist or even fascist overtone. The creation of Ukrainian academic centers independent or within the structure of, for example, Harvard, as well as the economic strength of these circles and their compactness, had almost no significance and it had no impact on the territory or the inhabitants of the Ukrainian SSR. The contemporary influence of these institutions or circles concerns mainly individual figures - representatives of the academic circles of today's Ukraine.

The lack of experience and the paucity of the Ukrainian elite, fascinated by the vision of the unification of a greater Ukraine from Bardejov to Kuban, explain little. The uncompromising attitude and radicalism of these elites was a weak substitute, and moreover, it led to the linking of the Ukrainian cause with the losing camp, which was known as early as January 1918. This meant a strategy of fighting against everyone and alliances with the defeated, and then participating in the so-called the "war 
of dwarfs" (November 1918-August 1921) in a situation of isolation or self-isolation. Distinct divergences among Ukrainian political leaders, united mainly by the Brest myth and anti-Polonism, also had a negative effect. It should be noted that as early as February 1918, it was a political mistake to ally the UPR with the party that was clearly losing the war, though "stunned by successes" and apparently gaining an advantage in the war. The phenomenon of bewilderment with its successes also affected the Ukrainian elite at that time. This resulted in the isolation of Ukrainian diplomatic actions due to the fact that the armistice agreement of November 1918 obliged Germany to cancel the peace treaties concluded in Brest (Cieplewicz, Stawecki, 1990, p. 234).

The lack of international recognition for Ukraine was only partially mitigated not until 1920 by the Republic of Poland, which at the same time forced the recognition of their ally by Latvia and Finland in 1920. Finland's situation cannot, however, be treated entirely in the same way as Ukraine. On the basis of the double-ethnic Finnish-Swedish society, the Grand Duchy of Finland was established, which built its own state structures in 1809-1917. This was not hindered by the fact that the majority of the elites were Swedish and the masses were Finnish, which may be analogous to Eastern Galicia in the 1880s. Building its armed forces in December 1917 - January 1918, Finland used ethnically Swedish officer cadres from the former Russian army and defeated the Bolshevik military and political interference nearly on its own by April 1918. When the Germans, stunned by their successes between February and April 1918, decided to intervene in Finland (April 7, 1918) at the formal request of the Finnish government's Pehr Evind Svinhaufvud, the Finnish commander-in-chief, General Carl Mannerheim, resigned on May 30, 1919 (Sołonin, 2014, p. 39-41). It was a move comparable to the reaction of Józef Piłsudski during the Oath crisis of the Polish Legions in World War I and Royal Polish Army in the summer of 1917. Then the Finnish politician and general, also a Swedish aristocrat, copied the tactics of Roman Dmowski going to Western Europe, where he held talks with the leaders of the allied powers, creating a positive outlook for the young Finnish state. This was possible because Finland did not conclude an official alliance with the Central Powers, unlike Ukraine, so on December 12, 1918, Baron Carl Mannerheim - a Swede 
- became a Regent of Finland, and his homeland gained international recognition and relatively high political standing in the Entente countries.

In the first phase of the operational concept implementation (AprilJune 2020), all military goals were quickly achieved on the $11^{\text {th }}$ day. For a month, administrative structures were created and attempts were made to mobilize the UPR troops. It turned out to be ineffective due to war fatigue and probably as a result of earlier Russian, Soviet and Ukrainian mobilizations into Ukrainian territory. Taking into account the Ukrainian self-assessment of the mobilization base created by $2-1$ million. men capable of service, as well as material resources left by the Russian army and the hetmanate period, as well as the actual mobilization between December 8, 1918 and January 10, 1919, achieving significant results should be assessed as a premise of success. At the same time, however, it was a delayed failure, resulting in the further future, as the recruits appointed could not be used due to material shortages, and above all staff shortages. Admitting the UPRs of former Russian officers to the army turned out to be the only real source, but at the same time at the risk of a lack of loyalty or ideology. Moreover, Ukrainian ideology itself was an insufficient substitute for qualifications and competences. This factor, along with the mobilization, which was poorly prepared without material security, limited the continuation of conscription in January 1919. The numerical increase of the UPR troops from 20 to 100 thousand. it lowered the quality of the human factor and contributed to the transmission of anarchy. Nevertheless, mobilization resumed in April 1920, which proved to be quantitatively effective, but again burdened the quality of the Ukrainian troops. It was only then that an attempt was made to organize its own military education, which turned out to be clearly overdue. The third mobilization was attempted in October: personally efficient and disastrous in terms of material. The estimate of the potential exaggerated the possibilities of the young state. Relying on insurgent groups or anarchist movements was an illusion and was in fact a burden. The personal losses of the Ukrainian army cannot be explained by the epidemic threat, either Spanish flu or typhus, because this threat affected all sides - the armies involved in the war. A specific loss was the change of submission of the WUPR troops, which either passed to the volunteer army in November 1919, or 
to the Bolshevik troops (Legieć, 2003, p. 14-20, 26). At this stage, the ambiguity of the attitudes of the Ukrainian Galician Army (UGA) veterans and, concurrently the divergence in the activities of the Ukrainian representatives in Western Europe became apparent. This was contrasted with the full commitment of the troops and majority of politicians around Symon Petliura.

In second phase, dominated by crisis, it is important to emphasize the effective retreats of the Polish and Ukrainian allied troops and the success in forming a volunteer army of the Polish Armed Forces or Ukrainian troops hinging on unconventional sources of recruitment, outside their own territory, e.g. in POW camps. In May 1920, the Polish Armed Forces had 963,516 soldiers, including over 40,000 officers and over 155 thousand non-commissioned officers (Cieplewicz, Stawecki, 1990, p. 225-226 i 270). This number rose to over a million in July after the formation of the socalled volunteer army and the return to the country of the $5^{\text {th }}$ Rifle Division. On the other hand, the real mobilization potential of the Second Polish Republic and the Polish Armed Forces (WP) in December 1918 was estimated at 1,360,000 soldiers, not counting soldiers in active service or abroad, e.g. in the Blue Army. Such precise data could be obtained thanks to the Polish military administration established in November 1916 and functioning very efficiently in 1920. The quality of the Polish officer corps was significantly improved thanks to its own military education system, which was expanded in 1916-1920. Several dozen of the general staff (certified) officers were inherited from the armies of the partitioning powers, complemented by the number of about 100 educated in 1919-1920 at the War School of the General Staff in Warsaw (Tomaszewicz, 1997). Such a favorable situation has never arisen in the formation of UPR troops.

In the political base of both allied armies, however, there was a crisis in the context of the retreat, which was especially marked in comparison to the euphoria of the May military successes, and the real threat that ensued, at the turn of July/August 1920. It was to a lesser extent a military crisis than an internal crisis in the case of The Republic of Poland. On the other hand, in the political base of the UPR, there were differences between the UPR-WUPR and the attitudes and behaviour of whole military units. 
Some soldiers from the UGA came a crossing at the Czechoslovakian border, which should be considered a collective and organized desertion. Petliura himself was considering renegotiating agreements with Poland in those days. At that time, the Ukrainian army did not exceed 13,000. soldiers in action in the southern operation. Even in the militarily critical decade of August 10-20, 1920, the framework organization of the Ukrainian army in the $6^{\text {th }}$ infantry division and cavalry division were consciously maintained. In practice, the Ukrainian division was equivalent to the regiment at the time, but the framework organization allowed for the coordination of staffs and command systems, which would enable the development of troops up to 100,000 army in the event of an effective mobilization.It was still hoped that mobilization could be carried out on both, the national territory and through unconventional forms. In practice, this turned out to be unattainable. The further development of events was determined by the consistent implementation of the Polish strategy applying the tactical effect of the Battle of Warsaw, although this was originally intended to be applied east of the Bug. The sense impending catastrophe, mainly among Ukrainian allies, undoubtedly triggered negotiations with Soviet Russia in July and August, alongside talks with the Entente powers in Paris or Spa.

The third phase of military operations was associated with taking over the operational initiative (Battle of Warsaw being a defensive operation), strategic (offensive operation being from the Wieprz River and the Battle of the Nemunas), and finally a political initiative taking advantage of the successes achieved in the operational depth until October 18,2020. In this phase, the organizational solidification of the URL troops progressed, although their significant numerical expansion was impossible. At the same time, groups of Ukrainian politicians competing to the UPR began to create parallel political or military structures in exile (in Czechoslovakia and Germany) between July 1920 and 1921. War fatigue also contributed to the reduction of Polish political or military goals, despite the effective expansion of troops in June-October 1920.

The two states united by the alliance: the Republic of Poland and the Ukrainian People's Republic did not manage to implement the entire strategic goal, and mainly failed to organize an effective Ukrainian state. 
This does not, however, diminish the fact that Poland, alone actively supported the Ukrainian cause and in the further post-war period, officially and unofficially. It attempted to sustain the alliance in feasible political and military forms. The Second Polish Republic did not formally terminate the agreements with its Ukrainian ally (April 21 and 24, 1920), despite the unequivocal provisions of the Peace of Riga. Poland, as the only allied state within the Entente, recognized the Ukrainian People's Republic among the three parallel entities aspiring to leadership in the Ukrainian state formations ${ }^{11}$. Soviet Russia understood this relatively quickly and forced Poles to recognize Kharkiv Ukraine as subject to international law. This can and must be viewed as Soviet manipulation in the light of the creation of the Union of Soviet Socialist Republics (USSR) a year later and the reification of the Ukrainian Soviet Socialist Republic (UkSSR). This involved, among other things, depriving it of the attributes of statehood, e.g. in the form of the elimination of diplomatic embassies in foreign countries, including the liquidation of the Polish mission in Kharkiv, which fell to the rank of a consulate.

Normally, when an important or ground-breaking historical event, such as the "Miracle on the Vistula River and the Battle of Warsaw", turns into a myth, it then becomes negative meaning. I suggest different optics, looking for a more positive interpretation. It could be found in a constitutive factor of the society of the Second Polish Republic, consolidating and uniting most with a functional state that is able to defend its independence and organize a national effort despite losses. Direct losses incurred by the Polish nation in the years 1914-1918 are 500-700 thousand fallen soldiers of Polish origin. However, in the years 1918-1921, under the conditions of the Second Polish Republic, it was about 350,000. soldiers, including over 100 thousand killed, and therefore irreversible losses. This juxtaposition shows both the pride of society in the achievements of the years 1918-1920 and the tragedy resulting in war fatigue.

11 The recognition of the UPR by Latvia and Finland, which were not allied states of the Entente, resulted from Polish pressure. At one time, as many as 5 Ukrainian state organisms existed, two of which turned out to be unstable. 
This was also a constitutive factor for the Ukrainian People's Republic as a state aspiring to the role of an entity in international relations and strive for all state attributes: legal and international, political, military and territorial. It was not possible to implement it in practice with the realities of 1918-1921. The Western literature is dominated by a legitimate view: "Poles can be forgiven for believing that in 1918 they won their own independence. However, it was not so ... But when they achieved independence at the end of the war (1918 - R.T.), they fought for it and defended it with boundless courage and determination "- this is the assessment of the polonophile prof. Norman Davies (Davis, 1995, p. 118). It was the result of the simultaneous collapse of the three partitioning empires, which at the same time became the enemy of the Entente in 1918-1919. Such a favorable configuration did not occur in the Ukrainian case, which was consistently treated as an internal Russian problem. All the more so because the Russian Empire had a huge potential, not used yet in 19191921, which was finally activated and used in the process of rebuilding its power by the Bolsheviks (Heller, Niekricz, 1985, p. 8-89).

The striving of the patriotic Ukrainian elite created opportunities for further prospects for sustaining Ukrainian issue throughout the $20^{\text {th }}$ century. In this approach, the following processes or events should be noted:

1. The most important thing was to maintain the continuity of the UPR in exile until 1940.

2. Maintaining the framework of Ukrainian military structures patterned after the Polish Armed Forces. The secret backbone structures of the Ukrainian armed forces were developed especially after 1926 and were based on two currents of work - supporting the development of officer cadres, and to a lesser extent noncommissioned officers, and creating a professional mobilization apparatus that existed until 1939. This path eliminated the mistakes made in 1918-1921.

3. The Volyn experiment (1926-1938) with reference to the ideology of 1920 designed from Polish-Ukrainian educational initiatives, and up to two initiatives to establish a university in Kremenets (independent of the work of organizing a Ukrainian university in the Second Polish Republic) (Kęsik, 2011, p. 92-98); 
4. An effort to create a Ukrainian regiment in the Polish Armed Forces in France (1939-1940). It was close to being realized, and although it had limited military significance, its international dimension could have been much greater. With this route, between September 1939 and June 1940, it would have been possible to add again an international dimension to the Ukrainian question. Later after June 22, 1941 up to1990 it was a non-starter.

5. Support in the years 1945-1946 by the Polish Armed Forces in the West for the prisoners of the Ukrainian army (of collaborative formations of the Nazi Germany).

6. In 1948, Ukrainian emigrants were incorporated into the promethean club of the Atlantic Charter with Polish aid. There was simultaneous obstruction by the Organization of Ukrainian Nationalists (OUN-B), so some Ukrainian activists reacted by joining the Polish Federalist Club as early as 1948.

7. Establishment of the 'Paris-based Culture' (Kultura) by activists associated with the ideology of 1920 and the formulation of its Eastern program.

8. The London Declaration of November 28, 1979 of Polish and Ukrainian governments in exile on cooperation to gain independence, lost by Ukraine in 1920 and by Poland in 1945 .

9. Adoption in 1976 of the Polish Independence Agreement, and in 1980 by the Polish intelligentsia (the opposition) of the 'Parisbased Culture's' eastern program as the cornerstone for PolishUkrainian relations.

10.Pro-Ukrainian initiatives in Polish diplomacy in 1989-1992 headed by prof. Krzysztof Skubiszewski, and promoting bilateral relations without the mediation of third parties and with the exclusion of mutual claims. The actions of Janusz Jabłoński, the Minister Plenipotentiary and Consul General of the Republic of Poland in Kharkiv, mainly in the spheres of science and education, were a further, and even a modern, perspective of this strategy.

11.A proposal by Ukrainian President Leonid Kravchuk in the spring of 1993 of "a pact extending from the Baltic to the Black Sea" with 
Poland and Ukraine in leadership, which meant an unintended reminiscence of the idea of 1920 .

The myth of 1920, preceded by the effects of the earlier Brest myth (which was deeply absorbed by the Ukrainian side), also had harmful repercussions for both countries and societies. These were, above all, the destructive divisions of the Ukrainian elite in Ukrainian lands and in exile, distracting the efforts of the numerically limited Ukrainian educated $^{12}$. This also resulted in tendencies to deepen and consolidate antiPolish attitudes of Ukrainians and the dominant features of German concepts of the majority (all? - R.T.) of currents among the Ukrainian political class, including those referring to Marxism. Mistakes in Polish internal politics and in emigration up to 1989 were equally destructive, being influenced by the political divisions in the Second Polish Republic that persisted in the Polish community long after the war. The policy of the governments in exile contributed to this until 1979. Revindication issues also appeared during the riots of October '56 (June 1956-March 1957) in Poland.

Communist Polish and Soviet historiography contributed to the construction of a negative variety of the image and myth of the war of 1920 in the Polish People's Republic (PPR). In Poland, it was counterbalanced by academia and the war veterans of 1920 . Even in the final stage, censorship in the Polish People's Republic forced the authors of historical studies to ignore this issue. An example is an extensive study (959 pages) published in 1990 and submitted for publication in 1986, where there is no mention of the 1920 hostilities at all (Cieplewicz, Stawecki, 1990). A variation of the neo-Soviet narrative already in free Ukraine are the memories of former president Leonid Kuchma (Kuczma, 2004, p. 47 and 106-124), which is understandable and... surprising due to the author and the time of publication!It was a typical attempt to silence history, plus a critique of the ideology of 1920, despite that in Poland there was both a large amount of pre-war literature, trustworthy and credible university studies - most

12 Mass preparation of the Bolshevik elites of Ukrainian origin from the so-called korenization until the 1980s should be distanced. 
often as doctoral and postdoctoral dissertations ${ }^{13}$, and pretty widely available émigré literature from Paris, London and New York.

The issues of internal or external Polish-Ukrainian relations after 1945 were also distorted or rationed in social relations. It was not only an attempt to silence the guilt or avoid determining the proportionality of events, as in the case of resettlement of people of the UkSSR-PPR or the PPR-PPR. It was primarily an effort to undermine the ideology of 1920 as a positive program of relations in 1920-1938 (passive - through silence; active forgery - by creating false images of the past). The Polish side was also burdened by the approach of some historians or politicians to the question of the fate of Poles remaining in the UkSSR after 1920 in several compact enclaves. It is difficult to accept the term of the former Deputy Foreign Minister Grzegorz Kostrzewa-Zorbas about "Soviet people of Polish origin" (Snyder, 2009, p. 282), especially since he was then and is a member of the academic community. Anti-communism cannot be an argument in itself.

The harmful effects of the course of the events of 1920, and then the denial of the ideology of 1920, also burdens the Ukrainian political class. This concerns maintaining a negative narrative on the Polish issue, which all too often refers to the Brest myth or the "all or nothing" strategy, enforced by majority of Ukrainian leaders (Nieścioruk, 2008, p. 55 i 68). This resulted in a negative or hostile attitude towards the Polish state between 1919 and 1981 by the majority (all? - R.T.) of the armed Ukrainian units. Only a small portion of the Ukrainian army and those combatants of the war of 1920 took a different position. Their convictions were largely distorted after the generational change in Ukrainian politics by the students of the Academic House in Lviv as is seen in the slogan "let there be a devil, just not Poland and the commune". Generational change and the rise of extremism in the Ukrainian nationalist emigration contributed to a significant reduction in funding for it by the Ukrainian diaspora in the USA and Canada (Wysocki, 2003, p. 270-275). The same generally was proclaimed in relation to Poland by the leader-

13 Paradoxically, in the Polish People's Republic, qualifying research papers could not be censored. Only their circulation was limited. 
ship of the USSR and the UkSSR until the mid-20 $20^{\text {th }}$ century. This is evidenced by the changing attitudes and views of, for example, Nikita Khrushchev.

For Ukrainian independence up to 1945, it meant wrong choices as to enemies and ill-chosen alliances made by politicians through 1959. In the case of the Ukrainian contestants or dissidents (after 1953) within the Ukrainian SSR, negative opinion of the idea of the 1920 were obviously accepted as historical truth, and the change was supposed to be only in the reform of communism. As a result, for Ukraine, this meant a change in the largest national minority, from Polish to Russian. The Soviet Empire achieved "historical justice" in 1939-1954 through aggression, collective displacement or exile, terror or deliberately induced famine (not only in the 1930s). In modern, free Ukraine, one can come across frequent assessments of academic teachers that the deportation of 480,000 of Ukrainians in 1944-1946 to the USSR was nothing else than the Polish Operation "Vistula", instead of what it was - forced on Poland by the USSR, the action of displacement mainly to the UkSSR as a form of implementing the Soviet "sobornost" with the participation of Soviet services and troops. As early as 1949, the UkSSR took the initiative to resume the deportations of Ukrainians from Poland to the USSR, which was confirmed by Molotov, who represented the central government in Moscow (Olejnik, 1998, p. 116-117).The UkSSR was to the same extent a unification state as was the Russian Empire until 1917. This policy, along with the self-isolation of the USSR, meant that the vicinity of the UkSSR and the Polish People's Republic was virtual. The prolonged effect of this was that even in the years 1991-2012 an external observer might have the impression that Ukraine has only one neighbour - the Russian Federation. This was contrasted by the transparency of European and international legal norms, which prof. Skubiszewski used as Polish Minister of Foreign Affairs. This means that an enduring international order is based on law, not revolution or violence.

Neither the two world wars nor the Polish-Soviet-Ukrainian war of 1920 led to the establishment of a stable and free Ukrainian state. Also, neither side of these conflicts (military, social and ideological) from 1914 to 1992 was interested in this. Imperial Russia wanted a territorial con- 
quest in which all "sub-Russians"14 could be gathered together and united completely with Russians. This was the goal of the empire builders as early as 1912, when the borders of the Congress Poland were adjusted, and then Count Alexei Bobryński in the years 1914-1915, who annexed Galicia and destroyed its culture. The new empire in the form of the USSR had the same goal in the 1920s, as in 1939-1945. It was achieved between 1944 and 1954 with the use of a complex and well-thought-out instrument: selective in time or the territory of "korenization", terror, movements of the population to and from Ukraine (in which the activities of the OUNUPA Organization of Ukrainian Nationalists - Ukrainian Insurgent Army in 1942-1946 proved to be a helpful), even if illusory and utopian, nevertheless effective ideology that transferred the conflict from the ethnocultural to the social/ideological plane, creating alternative career prospects for the Ukrainian educated classes on a supra-local level (in the USSR as $1 / 6$ of the globe) - both in the dimension of voluntary Russification-Sovietization and the deliberate process of "brain drain", that is, the appropriation of the most gifted group. As a result, Ukraine, always ethnically diverse, made further changes in ethnic diversity. The greatest loss, however, turned out to be the dominant element which was Soviet culture - if it really was culture?

The sobornost of the Ukrainian lands, implemented by the USSR in 1939-1954 as the only hegemon of social policy between the Oder and the Don, served to take control of the entire Ukrainian ethnic group, so that no part would remain outside the Empire as a leaven for independent aspirations or a cultural alternative to the Soviet UkSSR. This resulted in the forced resettlement of the Ukrainian population from Poland by the USSR: nearly 0.5 million by 1946 , and then dispersal of the remnants of 0.15 million in the north-western territories of the Polish People's Republic. What remained out of control, in exile, was effectively isolated until 1991.

At the turn of 1917/1918, Germany periodically took up the notion of supporting a satellite buffer state (UPR), but excluded it from the Mitteleuropa zone from the. It was part of the "bewilderment of successes"

14 Translator's note: "sub-Russians" - negative term for Ukrainians. 
caused by the break-up of Russia and temporary military successes in the West. The Ukrainian question was treated even more instrumentally in the years 1932-1945, making it impossible to even establish the foundations of statehood, despite the illusions of most Ukrainian elites. The choice of the German Reich as an ally was the same mistake as the alliance concluded on February 9 and March 3, 1918 in Brest. "We regret that the official Ukrainian factors went $100 \%$ to German concepts, we understand that the new Europe will be created according to English, not German recipes" - Borys Łewyckyj in October 1941. According to Volodymyr Kubiyjovych in 1943, "Poles were in a better position than Ukrainians who had no friends” (Grünberg, Sprengel, 2005, p. 569 i 587). Thus, the end of both world wars excluded Ukraine from peace deliberations, apart from the pressure from the USSR. Notwithstanding there was a periodic yet ultimately fatal phenomenon of stigmatization, that of good Soviet Ukrainians and Ukrainian collaborators of the German Reich (Krause, 2006).

The tragedy of the situation is best reflected in a German film of 2017, directed by Nick Baker-Monteys, "Leanders letzte Reise" ("The Final Journey"). Especially because this fictional picture perfectly reflects the inner drama of contemporary Ukrainian society as a result of the complicated history of Ukraine between 1917 and 2014. I believe that this is a picture that hides the deep, (though invisible directly in the plot) reasons for the inability to listen to (or the exclusion) of the Ukrainian side from the talks reorganizing Europe after World Wars I and II and the tragedy of Sovietization. From this process it is impossible to exclude both the subjectivity of the Ukrainian political class (self-exclusion as a result of mistakes made) and the consequences of the reification of Ukrainian society in the USSR, being treated as material for the upbringing of a unified Soviet man, as well as the reification of the Ukrainian question after 1945 through actions of extreme political (Ukrainian) groups took as clients of US intelligence until 1988. This was confirmed by the political naivety of universally recognized Ukrainian patriots as Pavlo Shandruk. Considering the harm inflicted on the greater European Ukrainian community in the course of constructing Europe after both world wars must therefore be accompanied by the mentioned elite accountability for the 
consequences of self-exclusion. General Władysław Anders, an excellent soldier, but just like General Pavlo Shandruk, not a very happy politician, was more cautious. Admittedly, both great patriots and honest soldiers met incidentally, as further contacts were consciously maintained indirectly by a Polish liaison officer. This did not prevent General Anders from giving the highest Polish decoration, the Virtutti Militari, awarded to Pavlo Shandruk in 1965. It was a highly political gesture, and highly controversial. Later, neither the Polish nor the Ukrainian side wanted to explain the controversy that arose. They were probably not interested in this despite the request of a Ukrainian historian in exile.

Although Ukraine was instrumentalized several times and excluded from international relations (or it excluded itself from the political negotiations of the winners of the wars), having a "sobornost" imposed by the Russians-Bolsheviks until 1954 - "The Ukrainian people finally received the state within the limits arbitrarily set by the leadership in Moscow". It is a free Ukraine that is satisfied, although it did not expect such a solution. The situation is similar to that of the Polish People's Republic. The reactions of both societies do not correspond to the tendency to dwell on the nefarious elements of the past and mutual historical relations, which inexorably marginalized the positive aspect of the 1920 war epic and the ideology of 1920 that arose from that background. How deeply entrenched were negative images and false historical narratives (enhancing shallow knowledge) worsened by the virtuality of the neighbourhood between 47 and 91? The immediate neighbourhood of the Polish People's Republic and free Ukraine for the subsequent 30 years has so far created merely opportunities for an exchange of views, though not extensive dialogue, only a rudimentary discourse.

\section{BIBLIOGRAPHY:}

Bruski, J.J. (2000). Petlurowcy. Centrum Państwowe Ukraińskiej Republiki Ludowej na wychodźstwie (1919-1924), Kraków: Wydawnictwo Arcana.

Cieplewicz, M., Stawecki, P. (21990). Zarys dziejów wojskowości polskiej w latach 18641939, Warszawa: wydawnictwo Ministerstwa Obrony Narodowej. 
Dąbrowski, J. (2015). Wielka Wojna 1914-1918, tom II, Oświęcim: Napoleon V.

Davies, N. (1995). Serce Europy. Krótka historia Polski, Londyn: Aneks.

Grünberg, K., Sprengel, B. (2005). Trudne sasiedztwo. Stosunki polsko-ukraińskie w X-XX wieku, Warszawa: Ksiązka i Wiedza.

Handelsman, M. (1993). Rozwój narodowości nowoczesnej. Warszawa.

Heller, M., Niekricz, A. (1985). Utopia u władzy. Historia Związu Radzieckiego, Londyn. Holzer, J. (2008). Polska i Europa „w Polsce czyli nigdzie”, Warszawa: Oficyna Wydawnicza RYTM.

Kęsik, J. (2011). Polityka szkolna wojewody wołyńskiego Henryka Józewskiego w latach 1928-1938. In. A. Haratyk (ed.), Rozwój polskiej i ukraińskiej myśli pedagogicznej na przestrzeni XIX $i$ XX wieku. Wrocław: ATUT.

Klimecki, M. (2002). Sojusz polsko-ukraiński 1920. In: B. Grot (ed.), Polacy i Ukraińcy dawniej i dziś. Kraków.

Klimecki, M. Wojna czy pokój. Polsko-ukraińskie negocjacje 1918-1921. In: Z. Karpus, W. Rezmer i E. Wiszka (ed.). Polska i Ukraina. Sojusz 1920 roku i jego następstwa. Toruń: Wydawnictwo Naukowe Uniwersytetu Mikołaja Kopernika w Toruniu.

Krause, W.H. (2006). Kozacy i Wehrmacht. Krakow.

Kuchma, L. (2004). Ukraina to nie Rosja, Kraków: Platan.

Legieć, J. (2003). Armia Ukraińnkiej Republiki Ludowej w wojnie polsko-bolszewickiej w 1920 roku. Toruń: Wydawnictwo Adam Marszałek.

Łysewicz, I. (1997). Polityczne aspekty sojuszu polsko-ukraińskiego 1920 roku. In: Z. Karpus, W. Rezmer i E. Wiszka (ed.). Polska i Ukraina. Sojusz 1920 roku i jego następstwa. Toruń: wydawnictwo Naukowe Uniwersytetu Mikołaja Kopernika w Toruniu.

Nieścioruk, J. (2008). Ustrój i polityka Zachodnio-Ukraińskiej Republiki Ludowej w latach 1918-1919. In: J. Marszałek-Kawa, Z. Karpus (ed.), Stosunki polsko-ukraińskie. Historia i pamięć. Toruń: Wydawnictwo Adam Marszałek.

Olejnik, L. (1998). Problem ukraiński w polityce narodowościowej państwa polskiego w latach 1944-1957. In: W. Bonusiak (ed.), Polska i Ukraina po II wojnie światowej. Rzeszów.

Pisuliński, J. (2013). Nie tylko Petlura. Kwestia ukraińska w polskiej polityce zagranicznej w latach 1918-1923. Toruń: wydawnictwo Naukowe Uniwersytetu Mikołaja Kopernika w Toruniu.

Snyder, T. (2009). Rekonstrukcja narodów. Polska, Ukraina, Litwa i Białoruś 1569-1999, Sejny: Pogramicze.

Snyder, T. (2010). Czerwony książe, Warszawa: Świat ksiązki.

Sołonin, M. (2014). 25 czerwca. Glupota czy agresja?. Poznań: Rebis.

Szlachtycz, S. (2008). Moje pół Ukrainy. In: J. Marszałek-Kawa, Z. Karpus (ed.), Stosunki polsko-ukraińskie. Historia i pamięć. Toruń: Wydawnictwo Adam Marszałek. 
Tomaszewski, R. (2015). Polska między Rosją a Niemcami w czasie I wojny światowej. In: Pierwsza wojna światowa w kontekście stosunków polsko-niemieckich. Zeszyty Kulickie, 11.

Tomaszewski, R. (2019). Polski i ukraiński wiek XX w perspektywie historii edukacji, Torun: Wydawnictwo Adam Marszałek.

Tomaszewski, R., (1997). Odbudowa polskiego szkolnictwa wojskowego w latach 1908-1923, Toruń: Wydawnictwo Adam Marszałek.

Wysocki, R. (2003). Organizacja Ukraińskich Nacjonalistów w Polsce w latach 1929-1939, Lublin: Wydawnictwo Uniwersytetu Marii Curie-Skłodowskiej w Lublinie. 